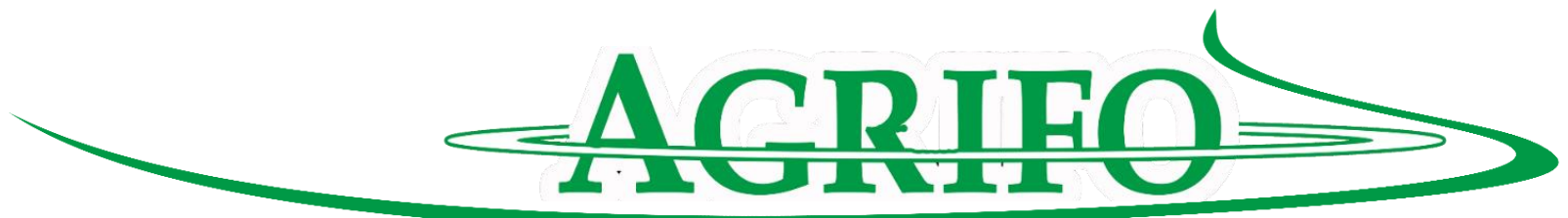

\title{
DINAMIKA KOMODITAS BERBASIS KEUNGGULAN LUAS LAHAN TANAMAN PANGAN KABUPATEN SUMEDANG PROVINSI JAWA BARAT
}

\section{Utan Sahiro Ritonga ${ }^{1}$}

Email Author: utanritonga@umbandung.ac.id

\section{ABSTRACT}

This research aims to know the dynamics of commodities based on the superior of food crops area in Sumedang regency of West Java within 10 years. Through the dynamics of commodity will be known food crops most suitable for development in Sumedang District. This research used quantitative descriptive method through LQ and DLQ analysis on land area of food crops at province and district level. Based on the dynamics of commodities based on land area of food crops, it is known that soybean is the only superior commodity of Sumedang Regency, with the acquisition value LQ > $1=1.2$ and DLQ $>1=2.4$. Wet land paddy and sweet potato are the mainstay commodities, because of the tendency of repositioning of superior commodities into non-superior commodities. Dry land paddy and peanut are prospective commodities, due to the tendency of repositioning of non-superior commodities to be superior commodities. While small green pea, cassava, and corn are lagging commodities which fix and remain a non superior commodity of Sumedang regency of West Java. The government can minimize the transfer of commodities by intensifying the provision of farming production facilities to support extension efforts to encourage each shifting the dynamics of commodities towards a more positive.

Keywords: dynamics, superiority, land, food, Sumedang

\section{PENDAHULUAN}

Dalam konteks pembangunan regional, pemerintah telah menggariskan suatu kebijakan yang menghendaki agar pembangunan tidak hanya dilaksanakan secara terpusat, tetapi harus ada kebijakan pengembangan ditingkat daerah yang bertujuan untuk menumbuhkan prakarsa maupun partisipasi masyarakat luas pada suatu wilayah untuk mendukung dan menyukseskan pelaksanaan pembangunan sesuai dengan kondisi daerahnya (Susanto, 2014).

Susilawati Pengembangan suatu wilayah adalah upaya untuk mendorong perkembangan sosial ekonomi wilayah, menghapus kesenjangan antara satu daerah dengan yang lainnya serta mampu menjaga kelestarian lingkungan hidup. Pembangunan nasional yang diarahkan pada pembangunan daerah, berdasarkan UU 32 tahun 2004 tentang Pemerintah Daerah pada dasarnya adalah untuk memacu pemerataan pembangunan dan meningkatkan kesejahteraan rakyat. Dalam hal ini peran serta pemerintah dan masyarakat sangat penting dalam pendayagunaan secara optimal dan terpadu atas potensi suatu wilayah.

\begin{tabular}{cccr} 
Menurut & \multicolumn{2}{c}{ Sudaryanto dan } \\
Rusastra (2006) & sektor pertanian
\end{tabular}

\footnotetext{
${ }^{1}$ Staff Pengajar Prodi Agribisnis Universitas Muhammadiyah Bandung
} 
memiliki beberapa multifungsi yang terkait berbagai aspek produksi maupun ketahanan pangan, peningkatan kesejahteraan petani atau pengentasan kemiskinan, dan kelestarian lingkungan hidup. Bagi Indonesia, nilai fungsi pertanian tersebut harus menjadi pertimbangan penting dalam menetapkan kebijakan struktur insentif sektor pertanian. Komitmen dalam mendukung insentif melalui pemahaman peran multifungsi sektor pertanian itu perlu diartikan secara luas, tidak hanya insentif ekonomi (subsidi dan proteksi), melainkan juga adanya dukungan pengembangan sistem agribisnis dalam arti luas.

Pengembangan sektor petanian melalui program kebijakan agribisnis yang sejalan dengan kondisi sosial ekonomi masyarakat akan mendukung pengembangan wilayah yang memiliki relevansi kuat terhadap sektor lainnya dalam pembangunan nasional. Alasan keberhasilan kebijakan itu adalah tindakan efisiensi program yang didukung sinergi kondisi potensi daerah seperti modal atas sumber daya alam serta sosial budaya tani.

Dalam strategi kebijakan pengembangan agribisnis pemerintah telah melakukan berbagai program terutama pada komoditas padi menurut Kusnadi dkk (2011); Wahyuni dan Indraningsih (2003) meliputi berbagai program seperti bimas, insus, supra insus dan lain sebagainya. Hingga Kementerian Pertanian pun merancang lagi dua program/proyek yaitu program Pengembangan Agribisnis (PA) dan program Peningkatan Ketahanan Pangan (PKP). Tetapi tujuan strategi kebijakan sepertinya belum mencapai efisiensi dengan alasan berbagai kendala yang dihadapi dalam kebijakan peningkatan tersebut.

Hal itu menunjukkan belum efisiennya upaya dalam mengatasi berbagai kendala teknis, sosial maupun ekonomi yang seringkali berlainan pada satu daerah dengan lainnya yang bersifat sangat lokal dan spesifik, atau sangat kondisional sekali. Hendayana (2003) Langkah menuju efisiensi bisa dilakukan dengan cara mengembangkan komoditas yang terdapat disuatu daerah yang mempunyai keunggulan secara komparatif dari sisi penawaran maupun permintaan komoditas. Dari sisi penawaran suatu komoditas unggulan mencirikan superioritas atas kondisi sosial ekonomi. Hidayah (2010) komoditas unggulan adalah komoditas yang layak diusahakan karena mampu memberikan beberapa keuntungan kepada petani secara biofisik dan sosial maupun ekonomi. Komoditas tertentu dikategorikan layak secara biofisik jika suatu komoditas yang diusahakan sesuai dengan zona agroekologi, layak secara sosial jika komoditas tersebut memberi peluang berusaha, bisa diterima untuk dikembangkan oleh masyarakat sehingga berimplikasi dalam menyerap tenaga kerja. Sedangkan memiliki kelayakan secara ekonomi berarti komoditas tersebut menguntungkan.

$\begin{array}{lr}\text { Pengembangan } & \text { komoditas } \\ \text { strategis seperti tanaman } & \text { pangan } \\ \text { berdasarkan komoditas } & \text { unggulan } \\ \text { sebagai basis ekonomi akan mendukung } \\ \text { ketahanan pangan dan mendorong } \\ \text { pertumbuhan ekonomi } r \text { wilayah. } \\ \text { (Juarsyah dkk, 2015) } & \text { komoditas } \\ \text { unggulan adalah komoditas } & \text { andalan } \\ \text { yang memiliki posisi r strategis, } & \text { tris } \\ \text { berdasarkan pertimbangan teknis } \\ \text { (kondisi tanah dan iklim), keadaan sosial }\end{array}$


ekonomi dan kelembagaan (penguasaan teknologi, kemampuan sumber daya manusia, infrastruktur, dan sosial budaya), untuk dikembangkan di suatu wilayah.

Wijaksana dkk, (2017) Peningkatan ekonomi pada suatu wilayah akan dilihat sangat baik apabila dapat memenuhi kebutuhan dari daerahnya sendiri dan juga dapat memenuhi kebutuhan daerah lain atau yang sering dikenal sebagai ekonomi basis. Dengan adanya basis ekonomi ini bisa dilihat potensi besar apa yang ada pada daerah tersebut sehingga akan terus dikembangkan agar dapat berkelanjutan karena bisa menjadi kontributor yang tinggi bagi perekonomian wilayah dengan memiliki pangsa pasar yang lebih luas bagi produk yang dihasilkan wilayah tersebut.

Hendayana (2003) Berdasarkan pemahaman pada teori ekonomi basis, pada umumnya teknik LQ relevan digunakan sebagai metode untuk menentukan komoditas unggulan dari sisi penawaran (produksi atau populasi) suatu komoditas. Untuk komoditas pertanian yang berbasis lahan seperti tanaman pangan, hortikultura dan perkebunan, perhitungan LQ berdasarkan pada keunggulan luas lahan pertanian.

Penentuan komoditas unggulan sebagai basis di suatu wilayah harus dilakukan dengan menyajikan data ramalan yang menunjukkan bahwa komoditas unggulan yang ditetapkan merupakan komoditas unggulan pada tahun-tahun sebelumnya, kini dan yang akan datang. Dengan alasan (Susilawati, 2016) bahwa basis ekonomi pada suatu wilayah tertentu tidak bersifat statis melainkan dinamis yang artinya pada tahun tertentu mungkin saja menjadi basis, namun pada tahun berikutnya belum tentu dengan sendirinya menjadi basis. Basis ekonomi bisa mengalami kemajuan ataupun kemunduran. Widyaningsih dkk, (2015); Ogari dkk,( 2014); Nurjayanti, (2012) menggunakan analisis DLQ (Dynamic Location Quotient) untuk dapat mengetahui ukuran dimasa mendatang suatu komoditas tertentu bisa bertahan sebagai unggulan atau tidak, atau komoditas yang sebelumnya bukan unggulan akan tetapi memiliki potensi sebagai subsektor dan komoditas unggulan di masa mendatang.

Berdasarkan analisis LQ dan DLQ dalam kurun waktu 2003-2013 menggunakan data PDRB, Widianingsih dkk, (2015) menyimpulkan bahwa sektor pertanian adalah sektor non basis pada sebagian besar kabupaten/kota di Provinsi Jawa Barat. Pada sebagian kecil kabupaten/kota di Jawa Barat menjadikan sub sektor tanaman bahan makanan dan hortikultura sebagai sektor basis atau unggulan.

Sementara Kabupaten Sumedang merupakan salah satu kabupaten di Provinsi Jawa Barat. Seperti yang diketahui bahwa Kabupaten Sumedang telah dikenal dengan komoditas unggulannya yakni ubi cilembu. Selain itu menurut Hoeridah dan Sarianti (2011) pada tahun 2004-2008, Dinas Pertanian Kabupaten Sumedang telah menentukan komoditas unggulan tanaman pangan selain ubi yaitu padi, jagung, kedelai dan kacang tanah. Dalam perspektif pengembangan wilayah dan ketahanan pangan maka perlu untuk mengetahui bagaimana dinamika keunggulan komoditas tanaman pangan 
berdasarkan luas lahan di Kabupaten Sumedang, sehingga dapat diketahui kecenderungan keunggulan dari tiap komoditas tanaman pangan yang ada sebagai dasar dengan tepat menentukan

kebijakan pengembangan komoditas tanaman pangan yang efisien dan paling sesuai dengan kondisi lokal yang mampu meningkatkan ketahanan pangan dan ekonomi wilayah.

\section{METODELOGI PENELITIAN}

Penelitian ini menggunakan metode penelitian deskriptif kuantitatif yang menurut Yusuf (2014: 62) merupakan usaha sadar dan sistimatis untuk memberikan jawaban terhadap suatu masalah dan/atau mendapatkan informasi lebih mendalam dan luas terhadap suatu fenomena dengan menggunakan tahap-tahap penelitian dengan pendekatan kuantitatif. Langkahlangkah dalam penelitian deskriptif (Noor, 2011:34) dimulai dengan adanya masalah, menentukan jensi informasi yang diperlukan, menentukan prosedur pengumpulan data melalui observasi atau pengamatan, pengolahan informasi atau data, dan menarik kesimpulan.

Data yang digunakan adalah data sekunder time series luas lahan komoditas tanaman pangan Kabupaten Sumedang dan Provinsi Jawa Barat selama kurun waktu 10 tahun, yang dikumpulkan dari Pusat Data dan Informasi Kementerian Pertanian RI.

Teknik analisa data untuk mengetahui dinamika komoditas berbasis luas lahan tanaman pangan Kabupaten Sumedang menggunakan LQ dengan rumus (Widyaningsih dkk, 2015; Ogari dkk, 2014; Sukmawani, et.al 2014; Nurjayanti, 2012; Hendayana, 2003) sebagai berikut:

$$
L Q=\frac{p i / p t}{P i / P t}
$$

Dimana:

pi $=$ luas areal tanam komoditas tanaman pangan komoditas i tingkat kabupaten $\mathrm{pt}=$ luas areal tanam seluruh komoditas tanaman pangan tingkat kabupaten $\mathrm{Pi}=$ luas areal tanam komoditas tanaman pangan komoditas i tingkat provinsi $\mathrm{Pt}=$ luas areal tanam seluruh komoditas tanaman pangan tingkat provinsi

Hasil perhitungan LQ menghasilkan tiga (3) kriteria yaitu:

(a) LQ $>1$ : artinya komoditas mendan jadi basis atau menjadi sumber pertumbuhan dan komoditas memiliki keunggulan komparatif, luas lahan produksi tidak saja dapat memenuhi kebutuhan di wilayah bersangkutan akan tetapi juga dapat diekspor ke luar wilayah.

(b) $\quad$ LQ = 1: komoditas tergolong non basis, tidak memiliki keunggulan komparatif dan luas lahan produksi hanya cukup untuk memenuhi kebutuhan wilayah sendiri dan tidak mampu untuk diekspor.

(c) LQ $<1$ : komoditas termasuk non basis dan luas lahan produksi komoditas di suatu wilayah tidak dapat memenuhi kebutuhan sendiri sehingga perlu pasokan atau impor dari luar wilayah.

Hasil perhitungan LQ selama kurun waktu yang dianalisis menunjukkan dinamika komoditas berdasarkan kriteria dengan kecenderungan keunggulan komoditas ditunjukkan oleh nilai rerata yang diperoleh. 
Selanjutnya untuk mengetahui dinamika komoditas berdasarkan keunggulan pertumbuhan luas lahan digunakan perhitungan DLQ (Widyaningsih dkk, 2015; Ogari dkk, 2014; Nurjayanti, 2012) dengan rumus:

$$
D L Q=\left[\frac{(1+g i j) /(1+g j)}{(1+G i /(1+G)}\right]^{t}
$$

Dimana:

DLQ = Indeks Dynamic Location Quotient komoditas i Kabupaten

gij = Laju pertumbuhan luas lahan komoditas tanaman pangan i Kabupaten gj = Laju pertumbuhan luas lahan subsektor tanaman pangan Kabupaten

$\mathrm{Gi}=$ Laju pertumbuhan luas lahan komoditas tanaman pangan i Provinsi

$\mathrm{G}=$ Laju pertumbuhan luas lahan subsektor tanaman pangan Provinsi

$\mathrm{T}=$ Kurun waktu analisis

Kriteria:

DLQ $>1=$ Komoditas masih dapat diharapkan untuk masa yang akan dating DLQ $<1=$ Komoditas tidak dapat diharapkan untuk masa yang akan dating

Berdasarkan kriteria yang ditetapkan dapat diketahui dinamika komoditas berdasarkan pertumbuhan luas lahan dalam kurun waktu yang dianalisis. Kecenderungan pertumbuhan komoditas sebagai gambaran keadaan pada waktu yang akan datang ditunjukkan oleh nilai rerata DLQ yang diperoleh.

Nilai rerata hasil analisis LQ dan DLQ kemudian digabungkan untuk mengetahui komoditas yang memiliki keunggulan luas lahan secara statis atau tetap dengan kriteria (Widyaningsih dkk, 2015; Ogari dkk, 2014; Nurjayanti, 2012) sebagai berikut:

(a) LQ > 1 dan DLQ > $1=$ Unggulan, maka komoditas belum mengalami reposisi dimasa mendatang.

(b) LQ $>1$ dan DLQ $<1$ = Andalan, maka komoditas telah mengalami reposisi dan tidak bisa diharapkan menjadi komoditas unggulan dimasa mendatang.

(c) LQ $<1$ dan DLQ $>1=$ Prospektif, maka komoditas telah mengalami reposisi dari komoditas non unggulan menjadi unggulan.

(d) LQ $<1$ dan DLQ $<1=$ Tertinggal, maka komoditas belum mengalami reposisi dan tetap menjadi komoditas non unggulan.

\section{HASIL DAN PEMBAHASAN}

Pada penelitian ini tidak semua data catatan luas lahan komoditas tanaman pangan tersedia di Pusat Data dan Informasi Kementerian Pertanian seperti yang direncanakan. Untuk luas lahan komoditas ubi kayu Provinsi Jawa Barat hanya dapat dikumpulkan data time series yang tersedia sejak tahun 2010 sampai dengan tahun 2015. Sementara untuk data time series luas lahan seluruh komoditas tanaman pangan Kabupaten Sumedang dapat terkumpulkan sesuai rencana yakni selama kurun waktu 10 tahun secara berurutan dari tahun 2006 sampai tahun 2015. Meski demikian keterbatasan ketersedian data luas lahan tersebut tidak menjadi penghambat hasil penelitian ini, karena sebenarnya untuk menginterpretasikan dinamika 
komoditas berbasis luas lahan secara komparatif menggunakan LQ dan DLQ dapat menggunakan data time series 5 tahunan seperti pada penelitianpenelitian lainnya (Ogari dkk, 2014; Nurjayanti, 2012).

Penggunaan tahun 2015 sebagai tahun akhir pengumpulan data dalam penelitian ini didasarkan pada alasan ketersediaan angka tetap luas lahan yang dapat disajikan Pusat Data dan Informasi Kementerian Pertanian. Kesenjangan antara tahun akhir dan tahun pelaksanaan penelitian tidak menjadi perhatian karena penelitian ini bertujuan mendeskripsikan secara kuantitatif dinamika keunggulan komoditas berbasis luas lahan tanaman pangan di Kabupaten Sumedang.

Dinamika komoditas berbasis keunggulan luas lahan tanaman pangan di Kabupaten Sumedang dalam kurun waktu 10 tahun dengan menggunakan analisis LQ dapat dilihat pada Tabel 1.

Tabel 1. Nilai LQ Berdasarkan Luas Lahan Komoditas Tanaman Pangan Kabupaten Sumedang

\begin{tabular}{|c|c|c|c|c|c|c|c|c|}
\hline \multirow[b]{2}{*}{ Tahun } & \multicolumn{8}{|c|}{ Komoditas } \\
\hline & $\begin{array}{l}\text { Padi } \\
\text { Sawah }\end{array}$ & $\begin{array}{l}\text { Padi } \\
\text { Ladang }\end{array}$ & $\begin{array}{l}\text { Kacang } \\
\text { Tanah }\end{array}$ & $\begin{array}{l}\text { Kacang } \\
\text { Hijau }\end{array}$ & $\begin{array}{l}\text { Ubi } \\
\text { Kayu }\end{array}$ & $\begin{array}{l}\text { Ubi } \\
\text { Jalar }\end{array}$ & Kedelai & Jagung \\
\hline 2006 & 1.3 & 0.8 & 0.1 & 0.5 & NA & 1.0 & 1.0 & 0.5 \\
\hline 2007 & 1.3 & 1.0 & 0.2 & 0.5 & NA & 1.7 & 1.3 & 0.6 \\
\hline 2008 & 1.3 & 0.8 & 0.1 & 0.3 & NA & 1.2 & 0.9 & 0.6 \\
\hline 2009 & 2.0 & 0.1 & 0.2 & 0.6 & NA & 1.9 & 0.6 & 0.9 \\
\hline 2010 & 1.3 & 0.8 & 0.1 & 0.4 & 0.5 & 1.0 & 0.4 & 0.5 \\
\hline 2011 & 1.3 & 0.7 & 0.1 & 0.5 & 0.5 & 0.7 & 0.5 & 0.5 \\
\hline 2012 & 1.2 & 0.8 & 0.1 & 0.3 & 0.5 & 0.7 & 0.7 & 0.6 \\
\hline 2013 & 1.2 & 0.8 & 0.1 & 0.5 & 0.5 & 0.8 & 1.3 & 0.6 \\
\hline 2014 & 1.1 & 0.9 & 0.1 & 2.0 & 0.5 & 0.9 & 2.4 & 0.6 \\
\hline 2015 & 1.1 & 1.2 & 0.1 & 2.4 & 0.4 & 0.8 & 2.8 & 0.6 \\
\hline Rerata & 1.3 & 0.8 & 0.1 & 0.8 & 0.5 & 1.1 & 1.2 & 0.6 \\
\hline
\end{tabular}

Sumber: Data Luas Lahan diolah, 2018

Keterangan: NA= Not Available/Data Tidak Tersedia

Pada Tabel 1. hasil perhitungan

LQ berbasis luas lahan komoditas tanaman pangan Kabupaten Sumedang dalam kurun waktu 10 tahun diketahui padi sawah berdasarkan dinamika luas lahan yang ada memiliki kecenderungan sebagai komoditas unggulan dengan nilai rerata LQ sebesar 1.3. Kedelai berdasarkan perolehan nilai selama kurun waktu yang sama diketahui memiliki keunggulan luas lahan di tahun 2007, 2013, 2014, dan 2015 sehingga berdasarkan dinamika tersebut memiliki nilai rerata sebesar 1.2 dan cenderung sebagai komoditas unggulan. Komoditas ubi jalar memiliki keunggulan luas lahan secara berurutan di tahun 2007, 2008, dan tahun 2009 dan memiliki kecenderungan sebagai komoditas unggulan setelah komoditas kedelai dengan nilai rerata sebesar 1.1. Sementara untuk komoditas lainnya tidak memiliki nilai rerata yang menunjukkan keunggulan, seperti 
kacang hijau hanya memiliki keunggulan di tahun 2014 dan 2015, padi ladang hanya memiliki keunggulan di tahun 2015, jagung, ubi kayu, dan kacang tanah tidak pernah unggul di Kabupaten Sumedang.
Sementara, dinamika komoditas berbasis keunggulan pertumbuhan luas lahan tanaman pangan Kabupaten Sumedang dapat dilihat pada Tabel 2.

Tabel 2. Nilai DLQ Berdasarkan Luas Lahan Komoditas Tanaman Pangan Kabupaten Sumedang

\begin{tabular}{|c|c|c|c|c|c|c|c|c|}
\hline \multirow[b]{2}{*}{ Tahun } & \multicolumn{8}{|c|}{ Komoditas } \\
\hline & $\begin{array}{l}\text { Padi } \\
\text { Sawah }\end{array}$ & $\begin{array}{l}\text { Padi } \\
\text { Ladang }\end{array}$ & $\begin{array}{l}\text { Kacang } \\
\text { Tanah }\end{array}$ & $\begin{array}{l}\text { Kacang } \\
\text { Hijau }\end{array}$ & Ubi Kayu Ub & i Jalar & Kedelai & Jagung \\
\hline 2007 & 0.8 & 0 & 9. & -0.1 & NA & 0.8 & 0.1 & -0.4 \\
\hline 2008 & -0.2 & -0 & 0 . & 0.0 & NA & 0.0 & 0.0 & 0.0 \\
\hline 2009 & 0.1 & 2 & 0 . & 0.0 & NA & 0.2 & 0.4 & 0.2 \\
\hline 2010 & -0.2 & 22 & -0 . & -0.5 & NA & 0.2 & 0.0 & -0.3 \\
\hline 2011 & -0.8 & 0 & 2. & 15.1 & -8.9 & -3.2 & 27.3 & 1.6 \\
\hline 2012 & 0.4 & 0 & 6. & -0.2 & 1.7 & 0.4 & 1.0 & -2.4 \\
\hline 2013 & 2.6 & -3 & -3 . & -64.9 & 2.1 & -36.8 & -9.7 & 0.4 \\
\hline 2014 & 0.1 & 0 & 0 . & -1.8 & 0.3 & 0.3 & 0.0 & 0.1 \\
\hline 2015 & 0.8 & 4 & 1. & 1.9 & 0.1 & 0.2 & 2.3 & 0.5 \\
\hline Rerata & 0.4 & 2 & 1. & -5.6 & -1.0 & -4.2 & 2.4 & 0.0 \\
\hline
\end{tabular}

Sumber: Data Luas Lahan diolah

Keterangan: NA= Not Available/Data tidak tersedia

Berdasarkan perhitungan DLQ seperti terlihat pada Tabel 2. diketahui bahwa padi ladang dengan nilai rerata DLQ sebesar 2.9 menunjukkan kecenderungan komoditas padi ladang sebagai komoditas yang dapat diharapkan menjadi komoditas unggulan dimasa yang akan datang. Kedelai dengan perolehan nilai rerata DLQ sebesar 2.4 juga menunjukkan kecenderungan untuk menjadi komoditas unggulan yang dapat diharapkan dimasa yang akan datang, diikuti oleh komoditas kacang tanah dengan perolehan nilai rerata DLQ sebesar 1.7. Sementara komoditas padi sawah, jagung, ubi kayu, ubi jalar, dan kacang hijau tidak dapat diharapkan untuk menjadi komoditas unggulan di Kabupaten Sumedang pada masa yang akan datang.

Selanjutnya untuk mengetahui komoditas yang paling unggul berdasarkan dinamika keunggulan luas lahan tanaman pangan dapat dilihat pada Tabel 3. 
Tabel 3. Gabungan LQ dan DLQ Komoditas Tanaman Pangan Kabupaten Sumedang

\begin{tabular}{lrrcc}
\hline \multicolumn{1}{c}{ Komoditas } & Rerata LQ & Rerata DLQ & Kriteria & $\begin{array}{c}\text { Dinamika } \\
\text { Keunggulan }\end{array}$ \\
\hline Padi Sawah & 1.3 & 0.4 & LQ $>1 /$ DLQ $<1$ & Andalan \\
Padi Ladang & 0.8 & 2.9 & LQ $<1 /$ DLQ $>1$ & Prospektif \\
Kacang Tanah & 0.1 & 1.7 & LQ $<1 /$ DLQ $>1$ & Prospektif \\
Kacang Hijau & 0.8 & -5.6 & LQ $<1 /$ DLQ $<1$ & Tertinggal \\
Ubi Kayu & 0.5 & -1.0 & LQ $<1 /$ DLQ $<1$ & Tertinggal \\
Ubi Jalar & 1.1 & -4.2 & LQ $>1 /$ DLQ $<1$ & Andalan \\
Kedelai & 1.2 & 2.4 & LQ $>1 /$ DLQ $>1$ & Unggulan \\
Jagung & 0.6 & 0.0 & LQ $<1 /$ DLQ $<1$ & Tertinggal \\
\hline
\end{tabular}

Pada Tabel 3. diketahui bahwa padi sawah mengalami kecenderungan reposisi dari komoditas unggulan menjadi komoditas non unggulan dengan perolehan nilai $\mathrm{LQ}>1=1.3$ dan DLQ $<1=0.4$ sehingga padi sawah merupakan komoditas andalan. Padi ladang mengalami kecenderungan reposisi dari komoditas non unggulan menjadi komoditas unggulan dengan perolehan nilai $\mathrm{LQ}<1=0.8$ dan DLQ $>$ $1=2.9$ sehingga padi ladang merupakan komoditas yang prospektif. Kacang tanah mengalami reposisi dari komoditas non unggulan menjadi komoditas unggulan dengan perolehan nilai LQ $<1$ $=0.1$ dan DLQ $>1=1.7$ sehingga kacang tanah merupakan komoditas prospektif. Kacang hijau merupakan komoditas yang tidak mengalami reposisi dan tetap menjadi komoditas non unggulan dengan perolehan nilai LQ $<1=0.8$ dan DLQ $<1=-5.6$ dan merupakan komoditas tertinggal. Ubi kayu tidak mengalami reposisi dan tetap menjadi komoditas non unggulan dengan perolehan nilai $\mathrm{LQ}<1=0.5$ dan DLQ $<1=-1.0$ dan merupakan komoditas tertinggal. Ubi jalar mengalami reposisi dari komoditas unggulan menjadi komoditas non unggulan dengan perolehan nilai LQ > 1
$=1.1$ dan DLQ $<1=-4.2$ sehingga merupakan komoditas andalan. Kedelai merupakan satu-satunya komoditas tanaman pangan yang tidak mengalami reposisi sebagai komoditas unggulan di Kabupaten Sumedang dengan perolehan nilai $L Q>1=1.2$ dan DLQ $>1=2.4$. Sedangkan jagung tidak mengalami reposisi dan masih tetap menjadi komoditas non unggulan di Kabupaten Sumedang dengan perolehan nilai LQ < $1=0.6$ dan DLQ $<1=0.0$ dan merupakan komoditas tertinggal.

Dengan adanya dukungan data serta informasi yang akurat menurut Gunawan (2015) diharapkan dua fokus kebijaksanaan pembangunan pertanian yang ditempuh Pemerintah hendaknya terdiri dari upaya yakni: 1 . mengembangkan suatu sistem bagi ketahanan pangan berlandaskan pada keragaman bahan pangan, kelembagaan dan budaya lokal; dan 2. mengembangkan agribisnis yang berorientasi secara global dengan menciptakan produk dengan keunggulan kompetitif daerah berdasarkan kompetensi dan keunggulan komparatif sumber daya alam maupun sumber daya manusia. 
Putri, (2015) Di sektor pertanian, lahan adalah sumberdaya yang paling penting untuk petani dalam pembangunan pertanian itu sendiri. semua kegiatan produksi pertanian di Indonesia masih bertumpu pada lahan sehingga lahan berperan penting dalam kegiatan dalam menghasilkan kebutuhan pangan yang dibutuhkan oleh setiap manusia.

Secara nasional, menurut Purwaningsih (2015) petani tanaman pangan adalah subyek penting bagi ketersediaan bahan pangan dalam kemandirian pangan melalui swasembada pangan. Peningkatan alih fungsi lahan pada pertanian produktif berdampak pada ketersediaan pangan suatu wilayah dan secara nasional. Dampak alih fungsi lahan juga memungkinkan terjadinya penurunan tingkat kesejahteraan petani, atau berkurangnya tingkat ketahanan pangan bagi rumah tangga petani.

Menurut Suharyanto dkk (2016) UU No. 41/2009 mengenai Perlindungan Lahan Pertanian Pangan Berkelanjutan yang telah disusun guna perlindungan lahan pertanian yang produktif supaya tidak dengan mudahnya dikonversi menjadi lahan non pertanian. Lahan pertanian bagi pangan berkelanjutan adalah luas lahan pertanian yang telah ditetapkan untuk dilindungi dan juga dikembangkan secara konsisten untuk menghasilkan pangan pokok bagi kemandirian, ketahanan, dan kedaulatan pangan nasional. Sehingga harus benarbenar dapat diimplementaskan ke produk turunannya dalam bentuk peraturan daerah (Perda) di masingmasing kabupaten yang mengatur terkait luasan, lokasi, dan distribusinya.
Dalam kemandirian pangan melalui kebijakan pemerintah daerah perlu ditetapkan regulasi yang menitikberatkan pada kebijakan untuk mengatur perlindungan luas lahan agar tidak terjadi pergeseran jenis komoditas meski pun itu dalam lingkup subsektor tanaman pangan sendiri. Hal itu sangat mungkin dilakukan dengan upaya intensifikasi penyediaan sarana produksi usaha tani misalnya benih dan bibit yang tentunya akan sangat mendukung kegiatan penyuluhan untuk mendorong tiap-tiap pergeseran dinamika komoditas kearah yang lebih positif menjadi komoditas unggulan dari suatu wilayah.

\section{KESIMPULAN}

Hasil analisis yang telah dilakukan menunjukkan dinamika komoditas berbasis keunggulan luas lahan tanaman pangan Kabupaten Sumedang pada kurun waktu 10 tahun dengan kesimpulan sebagai berikut:

1. Dinamika komoditas berbasis keunggulan luas lahan menggunakan analisis LQ diketahui padi sawah memiliki kecenderungan sebagai komoditas unggulan dengan nilai rerata sebesar 1.3. Kedelai memiliki keunggulan luas lahan di tahun 2007, 2013, 2014, dan 2015 dengan nilai rerata sebesar 1.2 dan cenderung unggul. Komoditas ubi jalar memiliki keunggulan luas lahan secara berurutan di tahun 2007, 2008, dan tahun 2009 dengan rerata sebesar 1.1 dan cenderung unggul. Sementara untuk komoditas lainnya seperti padi ladang, kacang hijau, jagung, ubi kayu, dan kacang tanah 
berdasarkan

dinamika

keunggulan luas lahan tidak memiliki kecenderungan sebagai komoditas unggulan Kabupaten Sumedang.

2. Dinamika komoditas berbasis keunggulan luas lahan menggunakan analisis DLQ diketahui bahwa padi ladang dengan nilai rerata sebesar 2.9 menunjukkan kecenderungan sebagai komoditas yang dapat diharapkan menjadi unggulan dimasa mendatang. Kedelai dengan perolehan nilai rerata sebesar 2.4 juga menunjukkan kecenderungan komoditas akan menjadi komoditas unggulan yang dapat diharapkan dimasa yang akan datang, dan diikuti oleh komoditas kacang tanah dengan perolehan nilai rerata DLQ sebesar 1.7. Sementara komoditas ubi jalar, padi sawah, jagung, ubi kayu, dan kacang hijau tidak dapat diharapkan menjadi komoditas unggulan di Kabupaten Sumedang untuk masa yang akan datang.

3. Berdasarkan dinamika komoditas berbasis keunggulan luas lahan tanaman pangan diketahui bahwa padi sawah dan ubi jalar mengalami reposisi sehingga menjadi komoditas andalan. Jagung, ubi kayu dan kacang hijau tidak mengalami reposisi sehingga menjadi komoditas tertinggal. Kedelai merupakan satu-satunya komoditas tanaman pangan yang tidak mengalami reposisi keunggulan luas lahan dan menjadi komoditas unggulan Kabupaten Sumedang.
4. Pemerintah dapat meminimalkan alih jenis komoditas melalui intensifikasi penyediaan sarana produksi usaha tani misalnya pengadaan benih dan bibit yang akan sangat mendukung upaya penyuluhan untuk mendorong tiap-tiap pergeseran dinamika komoditas kearah yang lebih positif menjadi komoditas unggulan Kabupaten Sumedang.

\section{DAFTAR PUSTAKA}

Hendayana, Rachmat., 2003. Aplikasi Metode Location Quotient (LQ) Dalam Penentuan Komoditas Nasional. Informatika Pertanian Volume 12 (Desember 2003)

Hoeridah, Ana dan Tintin Sarianti., 2011. Analisis Dayasaing Ubi Jalar Cilembu Di Kabupaten Sumedang Jawa Barat. Forum Agribisnis. Vol 1 No 2 September 2011. hlm 200 - 216.

Gunawan, Ikhsan. 2015. Analisis Strategi Pengembangan Usaha Komoditas Unggulan Pertanian Di Kabupaten Rokan Hulu. Jurnal Sungkai Vol. 3 No. 2, Edisi Agustus 2015 Hal: 1-17.

Juarsyah, Rendra dkk., 2015. Kajian Pengembangan Agribisnis Komoditas Unggulan BuahBuahan Di Kabupaten Kubu Raya. Jurnal Social Economic of Agriculture, Volume 4, Nomor 1, April 2015, hlm 56-69.

Noor, Juliansyah., 2011. Metode Penelitian: Skripsi, Tesis, Disertasi dan Karya Ilmiah. Prenadamedia Group. Jakarta. 
Nurjayanti, E. D., 2012. Kontribusi Sektor Pertanian Dalam Perekonomian Wilayah Kabupaten Pati. MEDIAGRO. VOL 8. NO. 2, 2012: HAL 21 31.

Ogari, P. A. dkk., 2014. Penentuan Komoditas Unggulan Pertanian Kabupaten Ogan Komering Ulu Timur. Agro Ekonomi. Vol 25/No. 2 Desember 2014. 160168.

Purwaningsih, Yunastiti dkk., 2015. Analisis Dampak Alih Fungsi Lahan terhadap Tingkat Ketahanan Pangan Rumah Tangga Petani di Karanganyar, Jawa Tengah. Jurnal AGRARIS Vol.1 No.2 Juli 2015.

Putri, Z.R., 2015. Analisis Penyebab Alih Fungsi Lahan Pertanian Ke Lahan Non Pertanian Kabupaten/Kota Di Provinsi Jawa Tengah 2003-2013. EKOREGIONAL, Vol.10, No.1, Maret 2015.

Sudaryanto, Tahlim dan I W. Rusastra., 2006. Kebijakan Strategis Usaha Pertanian Dalam Rangka Peningkatan Produksi Dan Pengentasan Kemiskinan. Jurnal Litbang Pertanian, 25(4), 2006.

Sukmawani, Reni et.al., 2014. Determining Agricultural Superior Commodity in The District of Sukabumi Through A Combination Method of $L Q$, Description Scoring, and Competitive Analysis. Research Journal of Agriculture and Environmental Management.
Vol. 3(11), pp. 599-604, November, 2014.

Suharyanto, dkk., 2016. Faktor Penentu Alih Fungsi Lahan Sawah Di Tingkat Rumah Tangga Petani Dan Wilayah Di Provinsi Bali. Jurnal Pengkajian dan Pengembangan Teknologi Pertanian, Vol. 19, No.1, Maret 2016: 9 - 22 .

Suryana, Ahmad., 2008. Menelisik Kebijakan Pangan, Kebijakan Pangan dan Swasembada Beras. Pengembangan Inovasi Pertanian 1, 1-16.

Susanto, Heru., 2014. Kajian Komoditas Unggulan, Andalan Dan Potensial Di Kabupaten Grobogan. Journal of Rural and Development Volume V No. 1 Februari 2014.

Susilawati, I. d., 2016. Penentuan Komoditas Unggulan Sektor Pertanian Tanaman Pangan di Kabupaten Bone, Sulawesi Utara. Prosiding Temu Ilmiah IPBLI 2016.

Wahyuni, Sri dan K. S Indraningsih., 2003. Dinamika Program Dan Kebijakan Peningkatan Produksi Padi. FORUM PENELITIAN AGRO EKONOMI. Volume 21 No. 2, Desember 2003 : 143 156.

Widianingsih, Wiwin dkk., 2015. Kontribusi Sektor Pertanian Pada Pertumbuhan Ekonomi Di Provinsi Jawa Barat. Agro Ekonomi Vol. 26/No. 2, Desember 2015. 
Wijaksana, dkk., 2017. Kontribusi dan Elastisitas Subsektor Dalam Sektor Pertanian di Kabupaten Tebo. Jurnal Paradigma Ekonomika Vol. 12. No. 2, Juli-
Yusuf, A. M., 2014. Metode Penelitian Kuantitatif, Kualitatif \& Penelitian Gabungan. Prenada Media Group. Jakarta. 